九州大学学術情報リポジトリ

Kyushu University Institutional Repository

PCR-RFLP Analysis of Amplified 28S Ribosomal

DNA for Identification of Rhizoctonia spp., the Causal Agents of Sheath Diseases of Rice Plants

Matsumoto, Masaru

Laboratory of Plant Pathology, Faculty of Agriculture, Kyushu University

Furuya, Naruto

Laboratory of Plant Pathology, Faculty of Agriculture, Kyushu University

Matsuyama, Nobuak i

Laboratory of Plant Pathology, Faculty of Agriculture, Kyushu University

https://doi.org/10.5109/24128

出版情報 : 九州大学大学院農学研究院紀要. 41 (1/2)，pp. 39-44，1996-11. Kyushu University バージョン：

権利関係 : 


\title{
PCR-RFLP Analysis of Amplified 28S Ribosomal DNA for Identification of Rhizoctonia spp., the Causal Agents of Sheath Diseases of Rice Plants
}

\author{
Masaru Matsumoto, Naruto Furuya and Nobuaki Matsuyama \\ Laboratory of Plant Pathology, Faculty of Agriculture, \\ Kyushu University, Fukuoka 812-81, Japan \\ (Received July 31, 1996)
}

\begin{abstract}
Isolates of five Rhizoctonia spp., the causal agents of sheath disease of rice plants, were characterized by the restriction fragment length polymorphisms (RFLPs) analysis of a $28 \mathrm{~S}$ ribosomal DNA (rDNA) gene amplified by the polymerase chain reaction (PCR). PCR-amplified products specific to AG 1-IA and AG 2-2 of $R$. solani, WAG-O of $R$. oryzae, AG-Ba of $R$. fumigata and AG-Bb of $R$. oryzae-sativae were selected and used for RFLP analysis. RFLP profiles obtained after digestion of 28SrDNA with the restriction enzymes were different depending on the four enzymes, HpaII, HhaI, Sau3AI and HaeIII, used. The RFLP profiles by the digestion with HpaII seemed to be useful for the benchmarks to discriminate Rhizoctonia spp.
\end{abstract}

\section{INTRODUCTION}

In Japan, causal agents of rice sheath blight diseases and similar diseases have been identified as multinucleate Rhixoctonia spp. such as $R$. solani AG 1-IA, AG 2-2 IIIB (Ogoshi, 1976; 1987) and $R$. oryzae WAG-O (Oniki et al., 1985) and binucleate Rhixoctonia spp. such as $R$. fumigata AG-Ba (Ogoshi et al., 1979; 1983) and $R$. oryzaesativae AG-Bb (Gunnell and Webster, 1987; Ogoshi et al., 1979). The symptoms caused by these Rhixoctonia spp. on rice sheath are very similar, and reliable identification by visual observation is often difficult. Therefore, studies on discrimination and/or diagnosis of these Rhixoctonia spp. would increase understanding of the symptomatological complex (Cubeta et al., 1991; Damaj et al., 1993).

These five Rhixoctonia spp. have been previously classified according to their ecology, morphology and hyphal anastomosis (Watanabe and Matsuda, 1966; Ogoshi, 1976; Ogoshi et al., 1979). Moreover, there have been many reports about molecular taxonomic studies on Rhizoctonia spp. (Duncan et al., 1993; Jabaji-Hare et al., 1990; Vilgalys and Gonzalez, 1990). Analysis of nuclear-encoded ribosomal DNA (rDNA) by restriction fragment length polymorphism (RFLP) revealed that different AGs in $R$. solani and binucleate Rhixoctonia spp. are genetically divergent (Liu et al., 1993; Liu and Sinclair, 1992; 1993; Cubeta et al., 1991). In the present study, an attempt was made to investigate the appropriation of molecular benchmarks for the discrimination and diagnosis of these Rhixoctonia spp. based on the results of PCR for amplification, followed by RFLPs analysis of nuclear-encoded $28 \mathrm{~S}$ rDNA.

This study was supported in part by the Grant-in-Aid from Ministry of Education, Science and Culture of Japan (N 0.07660061). 


\section{MATERIALS AND METHODS}

\section{Fungal isolates and maintenance}

Thirty isolates of Rhizoctonia spp. used in this study are listed in Table 1. The isolates were maintained on potato-dextrose agar (PDA, Funakoshi Chem. Co.) slants amended with $50 \mathrm{mg} / \mathrm{L}$ streptomycin sulfate at $25^{\circ} \mathrm{C}$ in dark. To prepare DNA samples for restriction analysis, three thin mycelial disks of each isolate cultured on PDA, $4 \mathrm{~mm}$ in diameter, were gently floated on $50 \mathrm{ml}$ of a liquid nutrient-broth medium (Difco) amended with $50 \mathrm{mg} / \mathrm{L}$ of streptomycin sulfate in $100-\mathrm{ml}$ flask and incubated at $25^{\circ} \mathrm{C}$ for 7

Table 1. List of investigated isolates of Rhizoctonia spp.

\begin{tabular}{|c|c|c|c|c|}
\hline Species & Isolate & $\mathrm{AG}$ & Source") & Origin \\
\hline \multirow[t]{10}{*}{ Rhizoctonia solani } & $\mathrm{Cs}-\mathrm{Ka}$ & $1 \mathrm{IA}$ & Rice & ATCC 76121 \\
\hline & $\mathrm{C}-325$ & $1 \mathrm{IA}$ & Rice & IFO 30935 \\
\hline & C-326 & $1 \mathrm{IA}$ & Rice & IFO 30936 \\
\hline & cs-2 & $1 \mathrm{IA}$ & Rice & AHU \\
\hline & Cs-Gi & $1 \mathrm{IA}$ & Rice & AHU \\
\hline & C-96 & 2-2 IIIB & Mat rush & ATCC 76124 \\
\hline & $\mathrm{c}-100$ & 2-2 IIIB & Mat rush & MAFF \\
\hline & C-116 & $2-2$ IIIB & Mat rush & MAFF \\
\hline & C-328 & $2-2$ IIIB & Rice & IFO 30944 \\
\hline & $\mathrm{c}-354$ & $2-2$ IIIB & Rice & $\mathrm{AKU}$ \\
\hline \multirow[t]{5}{*}{ R. oryzae } & Ro-0105 & WAG-O & Rice & $\mathrm{AMU}$ \\
\hline & M23 & WAG-O & Rice & AMU \\
\hline & $c-505$ & WAG-O & Rice & $\mathrm{AKU}$ \\
\hline & $\mathrm{R}-1$ & WAG-O & Rice & $\mathrm{AKU}$ \\
\hline & KAES-14 & WAG-O & Rice & $\mathrm{AKU}$ \\
\hline \multirow[t]{5}{*}{ R. fumigata } & TO-7 & $\mathrm{Ba}$ & Rice & AMU \\
\hline & TM-2B & $\mathrm{Ba}$ & Rice & AMU \\
\hline & KS-T1-3 & $\mathrm{Ba}$ & Rice & $\mathrm{AKU}$ \\
\hline & $\mathrm{K}-\mathrm{T} 1$ & $\mathrm{Ba}$ & Rice & $\mathrm{AKU}$ \\
\hline & $\mathrm{K}-\mathrm{T} 4$ & $\mathrm{Ba}$ & Rice & $\mathrm{AKU}$ \\
\hline \multirow[t]{5}{*}{ R. oryzae-sativae } & $93 \mathrm{Gi}$ & $\mathrm{Bb}$ & Rice & AMLJ \\
\hline & $94 \mathrm{~s}$ & $\mathrm{Bb}$ & Rice & $\mathrm{AMU}$ \\
\hline & KS-T2-4 & $\mathrm{Bb}$ & Rice & $\mathrm{AKU}$ \\
\hline & KS-T2-5 & $\mathrm{Bb}$ & Rice & $\mathrm{AKU}$ \\
\hline & $\mathrm{K}-\mathrm{T} 5$ & $\mathrm{Bb}$ & Rice & $\mathrm{AKU}$ \\
\hline
\end{tabular}

a) ATCC: American Type Culture Collection, USA.

IFO: Institution for Fermentation, Osaka, Japan.

AHU: Faculty of Agriculture, Hokkaido University, Hokkaido, Japan.

AKU: Faculty of Agriculture, Kyushu University, Fukuoka, Japan.

MAFF: Ministry of Agriculture, Forestry and Fisheries. Tsukuba, Japan.

AMU: Faculty of Agriculture, Meijyou University, Nagoya, Japan. 
days. The mycelial mat was harvested, washed repeatedly with water, lyophilized and then stored at $-20^{\circ} \mathrm{C}$ until use.

\section{Extraction of DNA and amplification with PCR}

Extraction of genomic DNA was done according to the procedure of Vilgalys and Gonzalez (1990) with slight modifications. The lyophilized and ground mycelia (30 mg) were homogenized in $450 \mu \mathrm{l}$ of extraction buffer $(50 \mathrm{mMTris}-\mathrm{HCl}, \mathrm{pH} 7.2,50 \mathrm{mM}$ EDTA, $1 \%$ sodium $N$-lauroyl sarcosinate, $1 \%$ 2-mercaptoethanol) and incubated at $65^{\circ} \mathrm{C}$ for 30 min. The homogenate was thoroughly shaken using $450 \mu \mathrm{l}$ of chloroform/phenol/ isoamyl alcohol $(24: 25: 1, \mathrm{v} / \mathrm{v} / \mathrm{v})$ mixture. After centrifugation for $15 \mathrm{~min}$ at $15,000 \mathrm{rpm}$, the water phase was collected and ammonium acetate was added so as to be $2.5 \mathrm{M}$. DNA was precipitated with $225 \mu 1$ of isopropanol and then collected by the centrifugation at 13,000 $\mathrm{rpm}$ for $15 \mathrm{~min}$. The pellet was washed with $70 \%$ aqueous ethanol solution, dried in vacuo, dissolved in $120 \mu 1$ of TE buffer (10 mM Tris-HCl, pH 8.0, $1 \mathrm{mM}$ EDTA) and incubated at $37.5^{\circ} \mathrm{C}$ for $30 \mathrm{~min}$ for treatment with ribonuclease A $(20 \mathrm{ng} / \mathrm{ml}$, DNase-free; Sigma, USA).

\section{Polymerase chain reaction (PCR)}

Two primers were synthesized for the amplification of a portion of $28 \mathrm{~S}$ rDNA repeat homologous to positions 17-1, 448 in the Saccharomyces cerevisiae 25S rRNA according to the procedure of Vilgalys and Hester (1990). Ten $\mu \mathrm{l}$ of 100 -fold dilution of DNA solution prepared by the above procedure was added to reaction mixture as recommended by the manufacturer using Tth DNA polymerase (TOYOBO Biochemicals, Co. Japan) in $100 \mu 1$ volume. The thermal cycles were conducted 30 times, with parameter of $1 \mathrm{~min}$ at $94^{\circ} \mathrm{C}, 2 \mathrm{~min}$ at $50^{\circ} \mathrm{C}, 1 \mathrm{~min}$ at $50-72^{\circ} \mathrm{C}$ for gradual increase and 3 $\min$ at $72^{\circ} \mathrm{C}$. After amplification, each sample was subjected to electrophoresis using a $1 \%$ agarose gel in TBE buffer (100 mM Tris-HCl, $20 \mathrm{mM}$ EDTA, $100 \mathrm{mM}$ boric acid, $\mathrm{pH}$ $8.3)$.

\section{Restriction fragment length polymorphism (RFLP) analysis}

After preparation of PCR-amplified rDNA, each PCR product was digested with 4 restriction enzymes (HpaII, HaeIII, HhaI and Sau3AI) and the sample was subjected to electrophoresis in a 3.5\% agarose gel (NuSieve, FMC Bioproducts) with TBE buffer.

\section{RESULTS AND DISCUSSION}

The $28 \mathrm{~S}$ rDNA products, a single $1.4-\mathrm{kbp}$ or 1.8 -kbp fragment, were detected by agarose gel electrophoresis following amplification with PCR (Fig. IA). A single 1.4-kbp fragment was obtained from two test isolates (WAG-O and $\mathrm{AG}-\mathrm{Bb}$ ) and 1.8-kbp one was obtained from remaining isolates (AG 1-IA, AG 2-2 IIIB and AG-Ba). Test isolates of AG 2-2 IIIB from mat rush and rice were used in this study, and the qualitative variation of PCR-amplified products of 28S rDNA was not observed (Data not shown).

RFLP profiles obtained by electrophoresis after digestion of PCR-amplified 28S rDNA represented specific fragment patterns (Figs. 1B-D, Table 2). After digestion of PCR- 

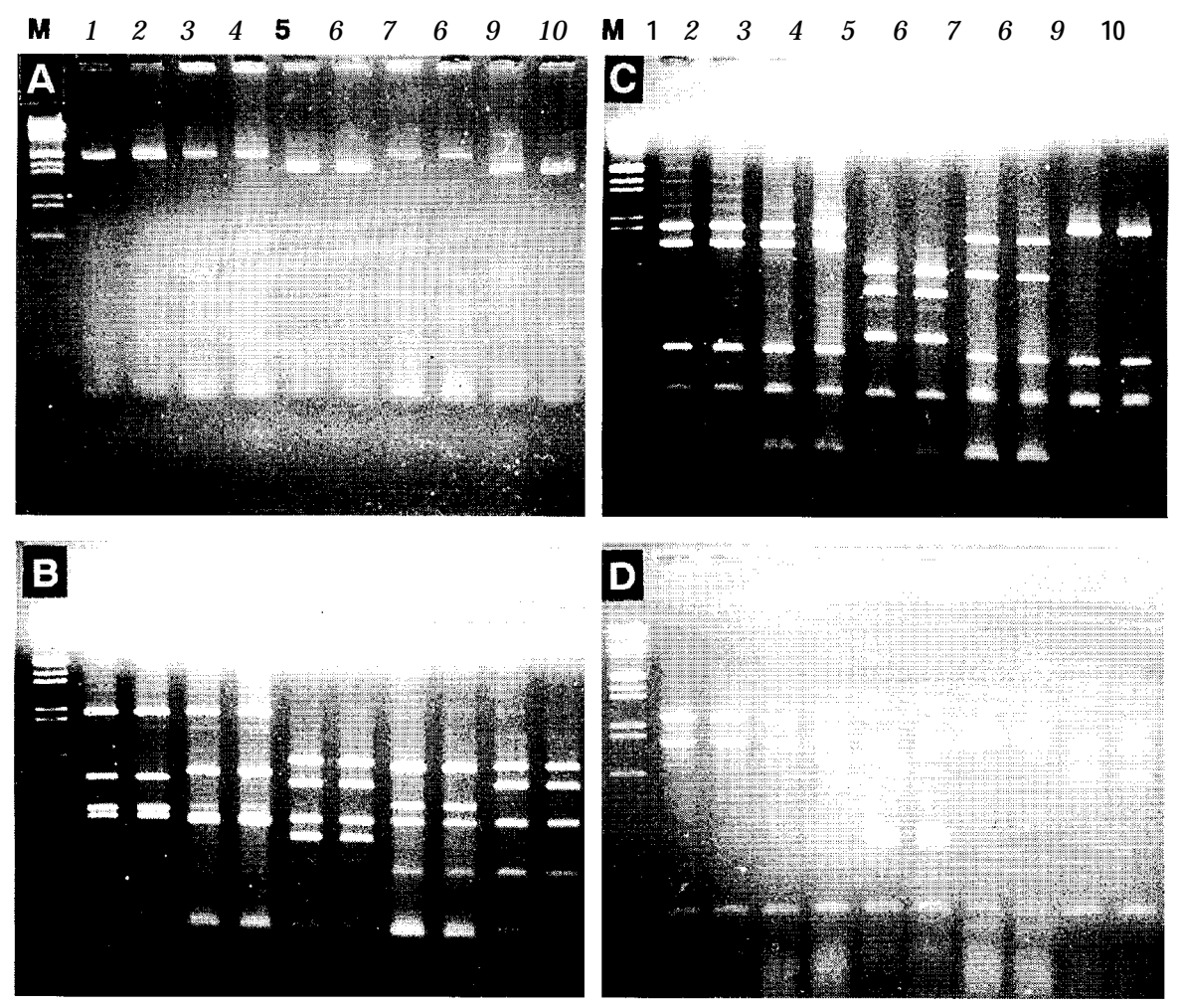

Fig. 1. The electrophoretic patterns of amplified 28SrDNA of Rhizoclonia sheath diseases of rice plant (A) and RFLP patterns of DNA fragments after digestion with HpaII (B), HhaI (C) and Sau3AI (D). Lane 1, Cs- Ka (AG 1-IA); Lane 2, C-325 (AG 1-IA); Lane 3, C-96 (AG 2-2 IIIB); Lane 4, C-354 (AG 2-2 IIIB); Lane 5, C-505 (WAG-O); Lane 6, Ro-0105 (WAG-O); Lane 7, TO-7 (AG-Ba); Lane 8, KS-Tl-3 (AG-Ba); Lane 9, 93Gi (AG-Bb); Lane 10, K-T5 (AG-Bb) and M, DNA size marker of J-DNA digested with EcoRI and HindIII (from top to bottom, 24756, co-migrating bands of 5148, 5148, 4937 and 4268, co-migrating bands of 2027 and 1904, 1584, 1375, 947, 831 and 564). Faint bands observed were non-specific products digested.

amplified 28S rDNA with HpaII, all isolates produced a common 290-bp fragment (Fig. 1B). RFLP profiles were different among isolates of each five Rhizoctonia spp. (Fig. 1B) After digestion of PCR-amplified rDNA with the enzymes HhaI, Sau3AI and HaeIII, all isolates produced a common 160-bp fragment (Fig. 1C), common 110- and 800-bp fragments (Fig. 1D) and common 150- and 220-bp fragments (Table 2), respectively. The isolates of AG 1-IA and AG 2-2 IIIB in R. solani showed identical RFLP profiles by digestion with each HhaI, Sau3AI and HaeIII. However, the profiles from these isolates were obviously different from WAG-O, AG-Ba and AG-Bb. Moreover, the isolates of each WAG-O, AG-Ba and AG-Bb showed different RFLP profiles and produced unique sets of 
Table 2. Sizes (bp) of DNA fragment generated after digestion of 28S rDNA from Rhizoctonia spp. with four restriction enzymes.

\begin{tabular}{|c|c|c|c|c|}
\hline \multirow[b]{2}{*}{ Anastomosis } & \multicolumn{4}{|c|}{ Restriction enzyme } \\
\hline & HpaII ${ }^{\mathrm{b})}$ & Hha I') & $\operatorname{Sau} 3 \mathrm{AI}^{\mathrm{d}}$ & HaeII") \\
\hline AG 1-IA & $310,450,900$ & $230,680,990$ & 950 & $200,330,450,500$ \\
\hline AG 2-2 IIIB & $280,500,900$ & $230,680,990$ & 950 & $200,330,450,500$ \\
\hline WAG 0 & $260,400,550$ & $260,390,480$ & 200,250 & 100,900 \\
\hline AG Ba & $170,330,500$ & $230,480,800$ & 900 & $180,250,450$ \\
\hline $\mathrm{AG} \mathrm{Bb}$ & $170,400,500$ & 230,990 & 550 & 450,550 \\
\hline
\end{tabular}

a) Represent 12 AGs of $R$. solani, AGs of $R$. oryzae and 16 Japanese AGs of binucleate Rhizoctonia species

b) All isolates produced a common 290-bp fragment after digestion with HpaII.

c) All isolates produced a common 160-bp fragment after digestion with HhaI.

d) All isolates produced common 1 10-and 800 -bp fragment after digestion with Sau3AI.

e) All isolates produced common 150- and 220-bp fragment after digestion with HaeIII.

fragments by digestion with each HhaI, Sau3AI and HaeIII (Fig. 1C-D, Table 2).

RFLPs detected at the electrophoresis after digestion of amplified 28SrDNA with HpaII, HhaI, Sau $3 \mathrm{AI}$ and HaeIII revealed the possibility of distinction of five Rhizoctonia spp. by this method (Fig.lB-D, Table 2). The isolates of AG 1-IA and AG 2-2 IIIB in $R$. solani showed identical RFLP profiles by the digestion with HhaI, Sau3AI and HaeIII, whereas the profiles by the digestion with HpaII were obviously different. These results would suggest that RFLP profile by digestion with Hpall will be available to use as molecular benchmarks to discriminate isolates of Rhixoctonia spp. Moreover, this method would involve the possibility of genetic diagnosis, and can be used for identification and characterization of isolates of Rhixoctonia spp. combining with anastomosis and the other properties.

\section{REFERENCES}

Cubeta, M. A., E. Echandi, T. Abernethy and R. Vilgalis 1991 Characterization of anastomosis groups of binucleate Rhizoctonia spp. using restriction analysis of an amplified ribosomal RNA gene. Phytopathology, 81: 1390-1400

Damaj, M., S. H. Jabaji-Hare and P. M. Charest 1993 Isozyme variation and genetic relatedness in binucleate Rhizoctonia spp. Phytopathology, 83: 864-871

Duncan, S., E. J. Barton and A. P. Brien 1993 Analysis of variation in isolates of Rhizoctonia solani by random amplified polymorphic DNA assay. Mycol.Res., 97: 1075-1 082

Gunnell, P. S. and R. K. Webster 1987 Ceratobasidium oryzae-sativae sp. nov., the teleomorph of Rhizoctonia oryzae-sativae and Ceratobasidium setariae comb. nov., the probable teleomorph of Rhizoctonia fumigata comb. nov. Mycologia, 79: 731-736

Jabaji-Hare, S. H., Y. Meller, S. Gill and M. P. Charest 1990 Investigation of genetic relatedness among 
anastomosis groups of Rhizoctonia solani using cloned DNA probes. Can. J. Plant Pathol., 12: 393-404

Liu, Z. L., L. L. Domier and B. J. Sinclair 1993 ISG-specific ribosomal DNA polymorphism of the Rhizoctonia solani anastomosis group 2. Mycologia, 85: 795-800

Liu, Z. L. and B. J. Sinclair 1992 Genetic diversity of Rhizoctonia solani anastomosis group 2. Phytopathology, 82: 778-787

Liu, Z. L. and B. J. Sinclair 1993 Molecular differentiation of intraspecific groups within anastomosis group I of Rhizoctonia solani. Can. J. Plant Pathol., 15: 272-280

Ogoshi, A. 1976 Studies on the grouping of Rhizoctonia solani Kühn with hyphal anastomosis and on the perfect stages of groups Bull. Nat. Inst. Agr. Sci. Ser., C30: 1-63

Ogoshi, A. 1987 Ecology and pathogenicity of anastomosis and intraspecific groups of Rhizoctonia solani Kuhn. Annu. Rev. Phytopathol., 25: 125-143

Ogoshi, A., M. Oniki, T. Araki and T. Ui 1983 Studies on the anastomosis groups of binucleate Rhizoctonia and their perfect states. J. Fac. Agric. Hokkaido. Univ., 61: 244-260

Ogoshi, A., M. Oniki, R. Sakai and T. Ui 1979 Anastomosis grouping among isolates of binucleate Rhizoctonia. Trans. Mycol.Soc. Japan, 20: 33-39

Oniki, M., A. Ogoshi, T. Araki, R. Sakai and S. Tanaka 1985 The perfect state of Rhizoctonia oryzae and R. xeae and the anastomosis groups of Waitea circinata. Trans. Mycol.Soc.Jpn., 26: 189-198

Vilgalys, R. J. and D. Gonzalez 1990 Ribosomal DNA restriction fragment length polymorphisms in Rhizoctonia solani. Phytopathology, 80: 151-158

Watanabe, B. and A. Matsuda 1966 Studies on the grouping of Rhizoctonia solani Kuhn pathogenic to upland crops. Bull. Appointed. Exp., 7: l-131 